\title{
"Much Given to Reading" A Literary Footnote on James McGill
}

\section{by S.B. Frost}

James McGill as merchant, magistrate, Member of the Legislative Assembly and of the Executive Council of Lower Canada, Colonel and Officer Commanding the Montreal Militia, was in his day one of the most promineni persons in the city. After his death in 1813, his name was perpeiuated by the college for which he had left endowment, but owing to particular circumstances, as a person he was quickly forgotten. Few personal papers or memorabilia survived into the later decades of the 19th century. However, among the rare memories recorded by Principal Dawson in an article written in 1870, was a reminiscence that Mc Gill was "much given to reading and full of varied information. "Dawson inferred from this that "he cultivated and enjoyed the society of the few men of learning "then in Lower Canada. Cultural opportunities were indeed few in a city that lacked schools, and where books, either French or English, were hard to come by. Dawson's inference is supported by McGill's lifelong interesî in efforis to obtain schooling, by the fact of his own solid education at Glasgow University, and by his later acquaintance with current literature, as exemplified by the works of Thomas Paine and T.R. Malthus. His own library appears to have included standard works, like Charles Rollin's Histoire Ancienne. When in 1810 the first Public Library was launched in Montreal, McGill was elected one of the Directors. Similarly, when the early school-masier Alexander Skakel assembled "philosophical apparatus" for experiments in optics, magnetism and "galvanism, "McGill was one of the Trustees appointed to oversee the use of the auxiliary funds collected by public subscription. Clearly, in his own lifetime, James McGill was widely recognized not only as a successful businessman and an assiduous public servant but also as a man of culture and intelligence.

Marchand, magistrat, membre de l'assemblée législative ei du conseil exécutif du Bas-Canada, colonel et officer de la milice, James McGill était à son époque l'une des personnalités les plus inffuentes de Montréal. Après sa inort en 1813, son nom esi perpétué par lé collège doni son legs permet la création mais des circonsiances pariculières font rapidement tomber sa personne dans l'oubli. Rares sont les documents ou objets personnels qui ont survéck aux dernières décennies du XIX siècle. Cependant, parmi les quelques souvenirs évoqués par le principal Dawson dans un article écrit en 1870, en apprend que McGill waimait beaucoup lire et connaissait maintes choses». Dawson en déduit que McGill "cultivait et appréciait la compagnie des rares érudits» qui vivaient alors dans le Bas-Canada. Les occasions de se cultiver étaient en effet minces dans une ville qui manquait cruellement d'écoles el où les livres, qu'ils soient en français ou en anglais, étaient difficiles à trouver. La déduction de Dawson est confirmée par les efforts que McGill n'a eu de cesse de déployer dans le domaine de la scolarisañion, par l'éducation très solide qu'il a reçue à l'Université de Glasgow et par sa connaissance de la littérature de son époque, comme en témoignent les oeuvres de Thomas Paine et de T.R. Malthus. Sa propre bibliothèque contenait vraisemblablemeni de grands classiques comme l'Histoire Ancienne de Charles Rollin. Lorsque la première bibliothèque municipale ouvre ses portes à Montréal en 1810, McGill fait partie de ses administrateurs. De même, quand l'un des permiers instituteurs, Alexander Skakel, décide de réunir du "matériel philosophique» pour des expériences d'optique, de magnétisme et de "galvanisme», McGill est au nombre des fiduciaires chargés de surveiller l'uililisation des fonds auxiliaires recueillis à l'issue de campagnes de souscription publiques. De son vivant, James McGill était connu comme un homme d'affaires prospère, un fonctionnaire accompli et un homme cultivé et intelligent.

I $\mathrm{t}$ is a curious fact that James McGill who as merchant, magistrate, militiă-ofíicer and Member of the Legisiative Assembly, was one of the best-known persons in the city (he was, reported The Gazettel of Montreal, "accompanied to the grave by an immense concourse of citizens of all classes") nevertheless within a few years of his deccase was almost wholly forgotten.

The ready explanation is that he had no 
affectionate family to nurture his memory. He had no children from his marriage to Charlotte Desrivières, his adopted daughter Charlotte Porteous predeceased him by fourteen months, his brothers John and Andrew, both also childless, were long dead. His wife's family, francophone and Catholic, despite being his fortunate heirs, had no natural affinity with their anglophone, Protestant benefactor, and the second and third generations quickly forgot him--all the more readily because twenty years of bitter litigation had alienated even the immediate heirs from those who were trying, in the face of great difficulties, to implement McGill's bequest "for the purposes of education and the advancement of learning in this Province". Archdeacon Jehoshaphat Mountain, lawyer Stephen Sewell, physician John Stephenson, who were trying to coax the still-born McGill College into life, were men of a new generation, none of whom had known the benefactor personally. The unfortunate breach between the Desrivières family and the College supporters was not repaired until 1875 , when the University asked the legal heirs of that time for permission to remove James McGill's remains from the former Protestant Cemetery in Dufferin Square to the campus for reburial under a restored tomb. The permission was quickly and generously given ${ }^{2}$. Relations were further strengthened two years later when Caroline Destivières, granddaughter of François Desrivières, Mrs. McGill's elder son, married Judge Thomas McCord, uncle of David Ross McCord, founder of the McCord Museum, who, probably through this connection, inherited James McGill's desk and a unique miniature portrait of him. Subsequent relations between the university and members of the Desrivières family have been uniformly cordial $^{3}$.

Nevertheless, irretrievable damage had been done. Personal memories, small anecdotes, precious papers, teil-tale memorabilia, the normal after-effects of an active, influential life, were neglected and lost, and the college, struggling to survive without the promised government support which McGill himself had envisioned, concentrated on the legal provisions of the bequest, and remembered the benefactor only in that regard. He had become merely a phrase, "the Founder". That signified his only remembered achievement, his Last Will and Testament his only words ever quoted.

Moreover, we have to recall that McGill himself was not a litte to blame. He was not the sort to generate much in the way of personalia. Business associate John Askin wrote to Isaac Todd, more than forty years after the McGill-Todd collaboration first began: "Nothing would be a greater loss to Mr. McGili than [that] of your Society; he loves you as a brother, and you always brought home dayly [sic] news, interesting and amusing, which he otherwise could not have had; his natural turn being not to mix, but with a few, chosen friends". All the information that has trickled down to us supports that comment. McGill was cleariy a self-reserved person; he had little small talk, did not express himself easily, especially on the rare occasions when his emotions were stirred deeply. When Charlotie Porteous, ("my amiable Miss Porteous", he called her, even though she had lived thirty years as a daughter in his home) was attacked by tuberculosis; he wrote to Askin that her illness threatened to "rid [deprive] us of the greatest consolation that either Mrs. MicGill or I possess", and that "her Situation rings my heart with woe" ${ }^{\text {.5 }}$. But when a few months later she did indeed die, his diary entry beginning the month of July 181.2 read "ist to 4 . weather sunny. blowing from w. to $\mathrm{n}$. and east. This moming at $20^{\prime}$ clock I had the distressing misfortune to lose Miss Porteous by decay ${ }^{n}$. MeGill was obviously a man of few words. He outlived most of his contemporaries, and when he passed away there were few in Montreal to cherish personal memories of him. Askin died in Upper Canada in 1815, Mrs McGill died in Montreal in 1818, Todd retired to England and died at Bath in 1819; Alexander Henry, seemingly indestructible, continued in Montreal until he passed away aged 85 in 1824, by which time McGill's once sirong persona had already faded.

For the next hundred years or so, the only one to show any interest in lames McGill as a person was Principal William Dawson. In 1870 he wrote an article for The New Dominion Monthly entitled "James McGill and His University"7. Here at least, James is not treated merely as an appendage to an. institution but as someone who rnight be venerated in his own right. The article is short, seven columns occupying three and a half pages, but three of those seven columns are concerned with McGill, and his intentions. Moreover, in this brief space, we not only get the bare facts of McGill's lifestory, but also what hitherto had been so woefully lacking, some few crumbs of personal reminiscence. Dawson had taken the trouble to enquire of the older 
generation still. living in Montreal when he arrived there in 1855; what memories they could muster of this man who had been so prominent in the city in their childhood and youth. Forty years is not a long period to ask the elderly to recall, but we all know that that kind of memory is very selective, and therefore we do not expect Dawson to have garnered a great deal. But what he does have to report is very interesting.

He is able to comment, for example, on McGill's physical appearance--"a tali and commanding figure", "in his youth a very handsome man.", "becoming corpulent in old age". One of Dawson's informants had evidentily been a member of the Beaver Club "and represents him, when a very old man, at one of the meetings, singing a voyageur's song with accurate ear and sonorous voice, and imitating, paddle in hand, the action of the bow-man of a 'North canoe' in ascending a rapid". It is a vivid little snap-shot. But Dawson is quick to add "But though taking his full share in the somewhat jovial social life of that early time, Mr. McGill was always esteemed a temperate man". Dawson does not mention that other tradition, that it was McGill who proposed that those who must go home to their wives should. leave at midnight, and that the doors should then be locked, so that rum, reminiscence and song might continue without interruption.

He goes on, however, to record that "the remembrance of another contemporary represents [McGill] as much given to reading and full of varied information". From this Dawson infers that "he cultivated and enjoyed the society of the few men of learning from the mother country". The purpose of this note is to draw together several items of information from other sources, which lend support to this bookish view of McGill's habits and personality.

McGill himself could with good reason claim to be one of the "men of learning then in the colony". He had attended grammar school and had matriculated at Glasgow University. He had received a good education in the classical languages (solid in Latin, probably less so in Greek) and stayed long enough to get a good knowledge of French, for he obviously had more than just the familiarity he acquired later in life with the voyageurs' patois. He was nominated in 1792 for election as Speaker of the first Legislative Assembly, "because he speaks both languages". He was not elected, the choice going to a unilingual francophone, but he was appointed to the committee charged with checking the translation of the proceedings into English or into French, as the case might be. His many written submissions to Government officials and the records of speeches made, reveal the discipline of an ordered and well-informed mind. Moreover, he could take his place effectively among the seven or eight men chosen to form the Governor General's Executive Council, a responsibility he fulfilled with great acceptance for twenty years ${ }^{8}$.

But Dawson was fuily justified in saying that the "men of learning" among McGill's contemporaries were few. The cultural poverty of the first generation of Montreal anglophones could hardly be exaggerated. There, were no public schools in Lower Canada unit five years after McGill's death; in 1818 the Royal Institution for the Advancement of Learning began to administer some thirty-five schools, mostly EnglishProtestant?. The few private schools which preceded them were for the most part little more than "dame schools" and seldom lasted long. The career of William Nelson, a London-trained schoolmaster, was exceptional; he came to the. Province in 1781 and settled at Trois-Rivières. He claimed that when he arrived there were only two other properly trained teachers in the Province. He moved to Montreal and taught there from 1790 to 1794 , but when his son Wolfred was three and his son Robert newly-born, he transferred to Sorei where he remained, running a school mainiy for the sons of British officers ${ }^{i 0}$. In 1790 there were said to be only eighteen. such ventures, of varying quality, serving an anglophone population of some $10,000^{\prime \prime}$. Montreal seems to have been left devoid of trained teachers until the arrival in 1799 of the Scot Alexander Skakel, M.A. of Aberdeen. He opened his Classical and Mathematical School in Little St James Street, but again it was not unitil five years after McGill's death that the school evolved inio a public institution with the name Royal Grammar School' ${ }^{12}$.

The commerce of printing and book-seling tells the same story. It is notorious that la Nouvelle France was never permitted to set up its own press; printing came to Quebec only at the beginning of the British period when two Americans, William Brown and Thomas Gilmore, began to pubilish the Quebec Gazetie . Montreal had to wait until 1776, when another 


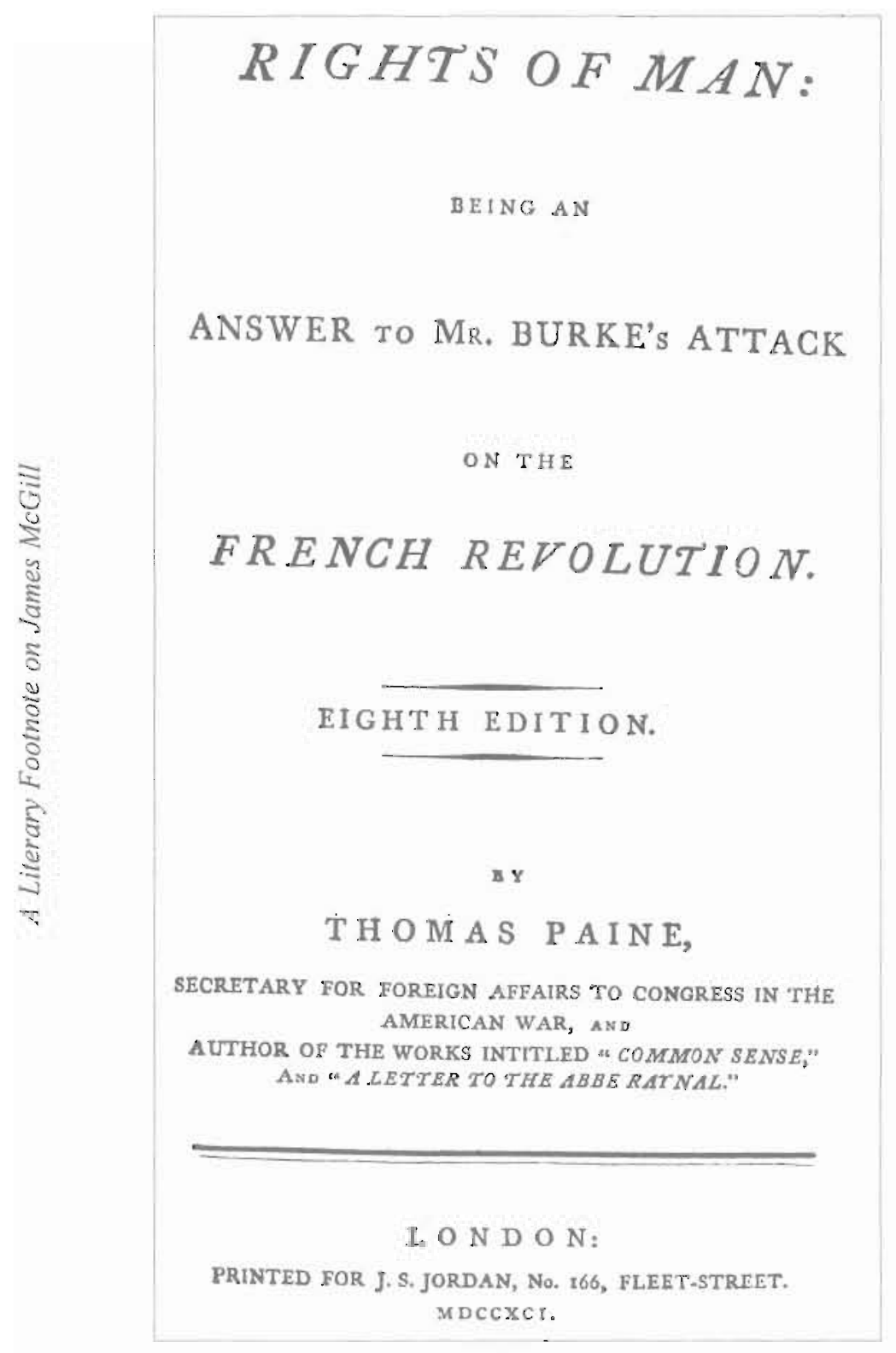

Figure 1

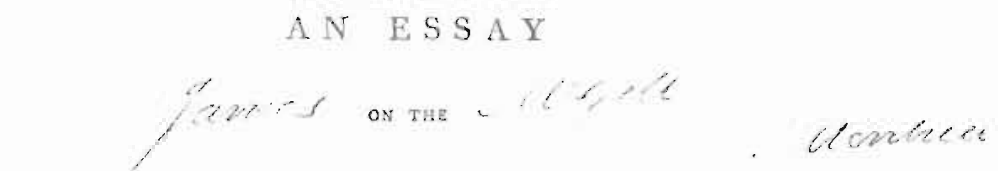

PRINCIPLE OF POPULATION;

$\mathrm{os}$,

A VIEW OF ITS PAST AND PRESENT EFEECTS

HUMAN HAPPINESS;

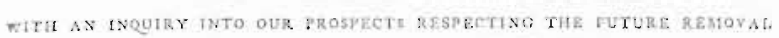

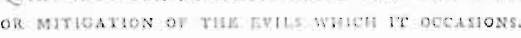

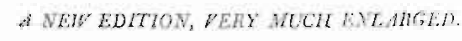

B) T. R. MALTHES, A. W

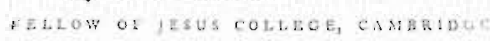

I. ONDON

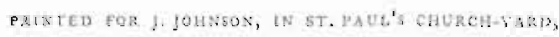

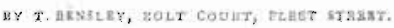

1803.

(Department of Rare Books and Special Collections, McGiil University Libraries) 


\section{A Literary Footnole on James McGill}

American, Benjamin. Franklin, brought along Fleury Mesplet to print revolutionary pamphlets, and, when that endeavour failed, Mesplet published Montreal's first news-sheet and (the only effort that generated any sales) little books of Catholic piety. John Duncan, a Scottish visitor, remarked gloomily as late as 1818 , that "the literature of the city may be estimated by the fact that there is but: one book-shop in it whose collection of English authors has even moderate claims to respectability"13

Nevertheless, there were from early times those who appreciated the companionship of books and could afford the high cost of gathering their own collections. In la Nouvelle France some private libraries could boast severail hundred volumes, and at leasi one neared the three thousand mark $^{14}$. After the inclusion of la Nouvelle France in the Province of Quebec under British jurisdiction, the importation of books from Britain or the Thirteen Colonies became much easier but, of course, imports from France and Europe were much more difficult. But administrators, Army officers and no doubt some merchants acquired reading matter for themselves, their wives and families. The military officers stationed on St. Helen's Island, for example, ran a small private library from 1778 until the withdrawal of the garrison at the time of Confederation's . Dawson's comments suggest that McGill was among those who possessed and enjoyed a private library.

We dearly wish he had kept a list of the books in his collection, and that a copy had survived into the present, for few things tell us more about a man than his reading. What little evidence we have suggests that McGill's bookshelves were well-stocked and the books themselves well-chosen. In January 1793, in a letter to John Askin he refers to Thomas Paine's Rights of $\mathrm{Man}^{16}$. (Fig. 1) The first part of this work was occasioned by the publication in 1790 of Edmund Burke's Reflections on the French Revolution. Rights of Man was published 13 March, 1791. Paine's second part was published in 17 February, 1792. Even if McGill's comment referred only to the first volume, knowledge of the work and its influence ("it would seem that the French Revolution and Mr. Paine's book on the rights of man have turned peoples heads") shows a surprising awareness of what was afoot in European and American literary circles. Books and papers took at least three months to arrive in. Montreal from Englana.

That McGill tried to keep abreast of the significant writing of his day, particularly in the area of politics and social theory, is supported by a unique item in the catalogue of the McGill. University Rare Book collection-a copy of Thomas Malthus' Essay on the Principal of Population, printed in 1803, bears the signature "James MoGill"17. (Fig. 2) The work was originally published. in England in 1798, but here is evidence that James McGill possessed the later edition and we may fairly presume, had made himself familiar with its contents, within a few years of its first appearance. We begin to understand his reputation for being "full of varied information."

A. well-informed mind rests on a foundation of broad and general knowledge, such as is gained from works designed for the general rather than the specialist reader. This is particularly true in the field of history; national histories are comprehensible only when viewed in the context of world history. One of the great $18 \mathrm{th}$ century educators of Europe was Charles Rollin, whose Histoire Ancienne in. 13 volumes, 1730-38, surveyed not only Greece and Rome but also Egypt, Babylonia and other civilisations. His work was said by later scholars, to be "distinguished for purity and elegance of style" if "deficient in critical sagacity" ${ }^{18}$. Nevertheless Rollin made Egypt, Greece and Rome live for generations not only of French readers but also of students throughout Europe generally, for he was much translated. English versions, of which there were several, began in 1739; the work was still being reprinted in France in 1827. Dr. Richard Virr, of the McGill Rare Book Depariment, has kindly informed me that in 1890, a sale catalogue advertised an odd copy of "Rollin's History, Volume 12" as bearing the signature "James McGill Montreal". Surely, McGill was not content with an odd volume of such a celebrated work, but acquired all thirteen. We hope some collector still cherishes that volume, and news of it encourages the thought that in libraries or in second-hand book-stores, there may yet be other works on dusty shelves bearing that same signature.

But of course all such private libraries were for the use of the owner and of his immediate circle. Towards the end of the 1.8th century, a new notion was arriving in Montreal- the icaea that a public library 
would help to serve the growing appetite for good reading, especially for those who could not, like James McGill, readily pay for their own reading materials. English publications were necessarily expensive items, whether they had been shipped across the ocean from Britain or imported from the United States. French books encountered additional difficulties. Because colonies were only supposed to trade with the "Mother Country", books from France were technically contraband. Those that were smuggled into French Canada had not been given clearance by the Church and were as often as not "the unwholesome works of the encyclopedists"19, which were frowned upon by the hierarchy. There was much to be said, therefore, for the institution of properly constituted public libraries.

An attempt to operate a circulating library on a commercial basis was made in Quebec City as early as 1.764 , at the very beginning of the British period, but it was soon abandoned as unprofitable. Governor General Sir Frederick Haldimand (in office 1778-84), a Swiss Protestant who seems to have been very wellintentioned but peculiarly insensitive to his charges' susceptibilities, spent $£ 500$ (a considerable sum) of his own money, to buy books both in French and English, in order to enlighten what he recognized was the woeful ignorance of the general population. To give the collection prestige, he required the Bishop of. Quebec to house it in the episcopal palace. That dignitary was much dismayed when he discovered the nature of the library, which drew largely on Protestant and current political and philosophical writers. Consequently, the hierarchy discouraged its use. The collection finally found its proper home with the Quebec Literary and Historical Society ${ }^{20}$.

In Montreal, the first truly public library was not launched until 1796. "The Montreal Library" was established as a joint-stock company, issuing 125 shares at $£ 10$ apiece ${ }^{21}$. We are not surprised to find that James McGill was elected one of the Directors of the Library. As one who valued reading, he welcomed this new venture, and participated wholeheartedly. Unfortunately, as Edgar Moodey, the historian of the Fraser-Hickson Library, observes: "Nothing is known of its membership, and little of its history, but it was obviously an exclusive circle which patronized it". Even its original. location is in doubt, but later it found a home in John Molson's New Mansion House hotel. which adjoined the Bonsecours Church. Shares at 乏10 each would limit the number of applications for admission, quite severely; perhaps the cost was intended to do so. The days of truly public libraries had not yet arrived, but "the Montreal Library" of 1796 was a beginning, and James McGill was one of its founders.

A. little removed from books and reading, but not from culiure, were the "natural philosophical" interests of the school master, Alexander Skakel. He was given to experimenting in the burgeoning new sciences of optics, magnetism and "galvanism", as well as with the new discoveries in chemistry. For these activities, he required apparatus, and the citizens of Montreal thought so well of his research and teaching in these areas that they subscribed $£ 400$ to help him procure what he needed $^{22}$. James McGill subscribed handsomely to the venture, and was invited to become one of the Trustees to oversee the use and administration of the funds. It is another indication that he was a well-educated man, "much given to reading, and full of varied information" and weil able to enjoy "the society of the few men of learning from the mother country then in the colony".

If keepers of records needed any defence, which in this Age of Information they assuredly do not, the story of James McGill's rehabilitation would certainly supply it. He was a great man in his day, a few years later he was quite forgotten, and remained so for a century or more. But fortunately archivists stored unconsidered legal records and librarians preserved the correspondence and occasional papers of obscure persons; public and academic libraries collected articles and pamphlets and books on the fur trade, on colonial, constitutional and all other kinds of hisiory. Consequently, researchers, including a Quebec Superior Court judge, a McGill graduate student, a self-described antiquarian, and others "given to much reading, "were able to piece the fragments together and reconstitute the persona of this man to whom we owe so much. The fact that we now have on campus a life-sized statue of James McGill striding out from his farm to serve his city and his province (see p. 22, Fig.5), symbolizes ? resurrection made possible by archives and archivists, libraries and librarians, and we gladly acknowledge our indebtedness. 


\section{A Literary Footnote on James McGill}

\section{Notes}

1. The Gazete, Montreal, 21 December, 1813.

2. McGill University Archives (MUA) Fact Sheet, 'James McGill's Tomb'. See E.H.Bensley, 'Is James McGill burted under the Ginkgo Tree?', McGull News 38, 18-19,45

3. In 1966 Alan Ridge the first University Archivist prepared a genealogical tree of the Desrivières family "from 1764 to the 20 th century". The present writer has also corresponded to mutual benefit with present-day members of the family.

4. Askin to Todd, 14 April, 1812; Askin Papers, Detroit Public Library Commission, 1931.

5. McGill to Askin, 14 February, 1812; MUA.

6. James McGill diary, Quebec Almanac, July 1812; MUA.

7. The New Dominion Monkhly, March 1870, 37-40.

8. For the details of McGill's life, see S.B. Frost, James Mc Gill of Montreal, McGill-Queen's Press, 1995.

9. R. Magnuson, Brief History of Quebec Education, 1980; 20.

10. 'William Nelson', Dicionary of Canadian Biography (DCB), VI, 536-37.

11. Magnuson, 18.

12. S.B.Frost, 'Alexander Skakel', DCB VI, 809-10.

13. G.R. Craig, Early Travellers in Canada, 1955: 57.

14. Magnuson, 9.

15. E.C. Moody, The Fraser-Hickson Library, 1977; 14.

16. MeGill to Askin, 20 January, 1793; Quaife i, 460.

17. See the reproduction of the titie page, p.12

18. Encyclopedia Americana, 1958, XXII, 636.

19. The phrase, used by a contemporary cleric, is quoted by E.C. Moodey from A. Drolet. Les biblioheques Canadiennes, 1640-1960. 1965.

20. Moodey, 14.

21. The proposal was advertised in The Gazene, 16 Feoviary. 1796.

22. 'Alexander Skakel', DCB VII, 809-10. 